\title{
E mbriões, células-tronco e terapias celulares: questões filosóficas e antropológicas
}

\author{
A N NE FAGOT-LAR GEAULT
}

A

VIDA DE U M A pessoa com insuficiência hepática aguda pode ser salva por um transplante de fígado, se um fígado estiver disponível (apósum acidente de trânsito ${ }^{1}$, por exemplo). A insuficiência renal é tratada a longo prazo pela diálise, mas está provado que um transplante de rim é o melhor tratamento para este quadro, por ser o tratamento menos dispendioso para a sociedade e porque ele dá ao receptor uma qualidade de vida bem melhor. U m transplante de células beta pancreáticas (produtoras de insulina) às vezes é proposto às pesso as atingidas pelo diabetes insulino-dependente severo cuja doença escapa ao tratamento clássico, para permitir-Ihes recobrar durante algum tempo 0 equilíbrio glicêmico sem a sujeição das injeções hormonais cotidianas. As afecções neuro-degenerativas (como as doenças de Parkinson, $\mathrm{H}$ untington e Alzheimer) são objeto, há algumas décadas, de tentativas experimentais de tratamento por transplante intracerebral de células nervosas coletadas de fetos provenientes de gravidez interrompida; os resultados são encorajadores. D esde quando se dispõe dos meios de combater a rejeição de transplante (ou seja, desde 1984 aproximadamente, data da comercialização da ciclosporina na França), os transplantes de órgãos e tecidos tornaram-se prática médica corrente, e os pacientes não se espantam mais que um transplante de córnea, de tecido ósseo, de intestino, de pele, talvez de face, Ihes seja proposto, nem que esses tratamentos sejam assumidos por um sistema de saúde solidário, a tal ponto que às vezes um direi to ao transplanteé reivindicado. Em nossos países de cultura judaico-cristã, a coleta de matéria biológica de corpos mortos é a regra; ela foi bem aceita e na França é encorajada por uma legislação que presume o consentimento do doador (desde a lei de 1976 relativa à coleta de órgãos, chamada "lei C aillavet", e essa disposição foi retomada pelas "leis de bioética" de 1994). A situação nem sempre é a mesma em outros países. $\mathrm{N}$ o J apão, por razões culturais e religiosas, a coleta de órgãos da pessoa morta foi proibida durante muito tempo, enquanto a coleta do doador vivo era mais tolerada.

Todos aprovamos o esforço recentemente empreendido para reduzir o número e a gravidade dos acidentes de trânsito. $\mathrm{N}$ em todos têm consciência de que a redução do número de mortes no trânsito cria (ou agrava) uma penúria de ór- 
gãos e tecidos destinados ao transplante. No que diz respeito à segurança no trânsito, estamos bem atrasados: outros países enfrentaram o problema antes de nós. H á muitos anos, os britânicos fixaram limites de idade ou condições restritivas para o acesso ao transplante no quadro do sistema nacional de saúde ( N H S). N os Estados U nidos 3 , foi calculado que, enquanto havia (em 2002) oitenta mil pesso as na espera de um transplante, não havia mais do que dez a doze mil óbitos de pessoas "úteis" para a coleta de órgãos, das quais apenas uma entre duas consentia em doar (na América do Norte o consentimento não é presumido: ele deve ser explícito). 0 recurso é insuficiente: se for levada em conta apenas a coleta da pessoa morta, nos E stados U nidos, a cada dia, quinze pacientes na fila de espera devem morrer por falta de órgão disponível. 0 autor do estudo americano (Etzioni, 2003) passa em revista as soluções que foram propostas: aperfeiçoar a coleta de órgãos nos corpos dos falecidos, fazendo, por exemplo, da doação, um dever cívico, como na Espanha, ou utilizando sistematicamente o corpo dos condenados à morte, como na China, ou atenuando a liberdade de opor-se à coleta, como na França. Ele julga que o rendimento desses métodos é muito fraco, o que pode explicar o desenvolvimento rápido nestes últimos anos de transplantes a partir de doadores vivos. Evidentemente, o transplante cardíaco não está envolvido; mas uma pessoa viva pode ser solicitada a oferecer um de seus rins, um pulmão, um pedaço de seu fígado, sua medula óssea, enfim, todo órgão ou tecido regenerável ou presente em dobro no organismo.

A organização da solidariedade entre vivos para a troca de órgãos vitais é exemplarmente a da transfusão de sangue. N o que diz respeito à doação de sangue, os Estados U nidos colocam em prática há vinte anos a ideologia desenvolvida em um livro de Robert Titmuss ${ }^{4}$, que criticava o sistema americano de comercialização de sangue. Titmuss mostrava, sobre uma base factual, que este sistema é perigoso para os doadores (eles vão dar demais), arriscado para os receptores (eles são contaminados mais freqüentemente) e que ele favorece o desperdício. E le argumentava a favor de um sistema não comercial, o qual favorece o altruísmo, encoraja o senso comunitário, contribui para elevar os padrões de qualidade e sobretudo evita a exploração sistemática dos pobres, dos desempregados, dos negros, de todos os que estão do lado desfavorecido da fratura social. Titmuss venceu. A retribuição de uma doação de órgão ou de tecido humano é proibida nos Estados U nidos desde o N ational Organ Transplant A ct de 1984.

$M$ as prestar-se a uma retirada de medula óssea, de um rim, de um lobo de fígado ou de pulmão, é uma operação mais arriscada do que uma doação de sangue. H ouve acidentes entre os doadores, alguns fatais, e complicações graves, particularmente durante as coletas de material do fígado. Para que os recursos se elevem à al tura das necessidades, é preciso incitar as pessoas a doar. I sto necessita uma reorientação da legislação: há uma série de projetos de lei atual mente sendo apresentados ao Congresso Americano que prevê a instituição de dispositivos incitadores, desde a medalha, ou o crédito de imposto, ou a cobertura social para 
toda vida, ou a inscrição de detentos nas listas de doadores mediante certas vantagens, até a retribuição financeira direta. A solução liberal por excelência seria a commodificação dos órgãos e tecidos humanos, isto é, sua colocação no mercado (mercantilização).

$\mathrm{N}$ ão chegamos a esta situação. M as uma leitura da literatura bioética recente mostra que pensadores americanos sensatos, moderados, estão tendendo para a posição liberal como sendo a menos ruim no estado atual das coisas. A argumentação procede como se segue, no contexto de uma moral do Bem: primeiro os pacientes. O s pacientes precisam de transplantes. É imperativo fornecêlos. É injusto deixá-los morrer.

É preciso, portanto, organizar-se para dispor de matéria-prima suficiente. Todo cidadão deve admitir que isto é uma prioridade de saúde pública, e se isto demanda compensações financeiras aos doadores, que elas Ihes sejam concedidas, é um mal menor (assim R obert Veath, 2003: "tolerate financial incentives as a lesser moral evil", p. 19). O detalhe dos argumentos que empurram alguns da doutrina da gratuidade para uma doutrina da justa compensação é interessante de observar. E ncontram-se primeiro os clássicos argumentos de que a gratuidade favorece o mercado negro, que os pobres poderiam tirar proveito da venda a um preço público (e em toda transparência) de um órgão não vital, que as partes de nosso corpo são como um patrimônio que cada um deve estar livre para gerir a seu modo etc. Estes argumentos, dirigidos contra a doutrina de Titmuss, não carecem de plausibilidade. É notório, por exemplo, que um insuficiente renal rico pode atualmente comprar um rim para ser transplantado em tal hospital do O riente M édio, e que a coleta mais ou menos clandestina de rins para esta finalidade implica a exploração de doadores pobres e mal informados. 0 utros argumentos são mais incisivos, assim como aquele que compara o compromisso do doador ao do bombeiro, do policial ou do militar. N ós temosum exército profissional. Consideramos normal pagar aqueles que se alistam voluntariamente neste exército. O ra, essas pessoas são pagas para arriscar sua vida (e às vezes morrer no combate). Mas é preciso que a nação seja defendida. Pagar aqueles que a defendem é um mal menor (seria pior não pagá-los!). U m outro argumento nos toca de perto, no momento em que se considera a redução, na França, da cobertura social dos cidadãos: em um sistema de saúde que não cobre todos os riscos, o mínimo que se pode (e se deve) fazer para os doado res vivos (que assumem um risco a serviço da coletividade) é garantir-Ihes uma cobertura social completa - e isto representa um custo financeiro mensurável, que equivale a um pagamento da doação.

N ossas "leis de bioética" ${ }^{5}$ não nos protegem contra a necessidade de uma reflexão sobre estes problemas. D e um lado, elas mantêm firmemente o princípio da gratuidade da doação (lei no 94-653, artigo 16-6). D e outro, estava previsto que elas fossem revisadas ao termo de cinco anos, ou seja, em 1999, e, após vários adiamentos, o exame definitivo pela Assembléia $\mathrm{N}$ acional do projeto ado- 
tado pelo Senado no início de $2003^{6}$ acaba de ser mais uma vez postergado para maio de 2004. Além disso, o texto atual só responde fracamente à questão colocada: se há menos mortos no trânsito (e nós não podemos não querer que seu número diminua), onde encontraremos os órgãos ou tecidos para transplantar? Sem dúvida, as restrições, até agora muito estreitas, para a coleta sobre o doador vivo, são um pouco atenuadas pelo atual projeto de lei. Aquele que precisa de um rim, ou de um outro órgão vital, poderá recebê-lo, não somente de um parente próximo (pai ou filho, mãe ou filha, irmão ou irmã), como o estipulava a lei de 1994, mas de um menos próximo (tio ou tia, primo de primeiro grau, cônjuge). Além disso, a medula óssea, passando da categoria dos órgãos à dos tecidos e células, poderá ser coletada para fins terapêuticos de um menor ou maior de idade legalmente protegido. A intervenção de uma junta de peritos e o regime previsto para o consentimento dos doadores, entretanto, tornam este procedimento complexo; e a manutenção estrita do princípio de gratuidade torna a doação menos provável à medida que o círculo de doadores potenciais se amplia.

C omo os doadores são incitados a doar? A A ssembléia N acional tinha considerado inscrever na lei o "reconhecimento da N ação" para as pessoas que doassem elementos de seu corpo para fins médicos ou científicos, mas o Senado anulou este dispositivo e o substituiu por uma autorização aos hospitais onde são efetuadas coletas de manter um "espaço de memória destinado à expressão do reconhecimento aos doadores de seu corpo para fins de transplante" (artigo 7-B, III , 4으, visando ao artigo 1233-3 do Codedela santé publique).Finalmente, se o projeto de lei autoriza, para um período limitado a cinco anos e com o consentimento do casal genitor, a pesquisa sobre os embriões "excedentes" originados da fertilização assistida (que seriam de outro modo destinados à destruição), ele proíbe não somente a clonagem de caráter reprodutivo, mas também a clonagem de caráter terapêutico, barrando assim uma via de pesquisa que poderia fornecer soluções alternativas. $\mathrm{N}$ a perspectiva de uma penúria de órgãos ou tecidos para transplante e na au sência de uma real proteção social dos doadores vivos, não há outra opção senão, entre uma restrição de acesso ao transplante (passiva: deixar morrer as pessoas inscritas na fila de espera; ou ativa: definir critérios de eligibilidade), o desenvolvimento sistemático do xeno-transplante (transplante de órgãos ou tecidos animais), e o desenvolvimento de órgãos artificiais (por exemplo, bombas cardíacas).

Xeno-transplantes foram freqüente e seriamente considerados e algumas tentativas foram realizadas (transplante de coração de babuíno), mas teme-se que o perigo de introduzir na espécie humana por esta via doenças (por exemplo virais) potencialmente perigosas, exceda a vantagem que haveria, por exemplo, em criar porcos "humanizados" 7 que forneceriam rins em grande quantidade para transplantes. Q uanto às máquinas miniaturizadas e implantáveis que supririam uma função renal, cardíaca ou pulmonar ausente, elas ainda não deram provas de serem viáveis; é possível que seu desenvolvimento tenha se ressentido do próprio 
sucesso dos transplantes de órgãos coletados de corpos mortos. R esta, portanto, considerar uma limitação de acesso ao transplante. Afinal, nenhum ser humano pode exigir a utilização de uma parte do corpo de outrem. U m americano atingido por leucemia quis outrora obrigar um membro reticente de sua família a doar-Ihe medula óssea; ele atacou-o na justiça, sua demanda foi indeferidå. É triste morrer aos vinte anos de uma hepatite aguda, ou aos cinqüenta de uma cirrose complicada por um câncer, mas a cada um o seu destino biológico: 0 transplante de fígado não é um direito.

A medicina, porém, não pode simplesmente renunciar a socorrer aqueles condenados por seu destino biológico. A pesquisa sobre as células-tronco abresIhe hoje novas possibilidades. As propriedades regenerativas dos seres vivos são conhecidas há muito tempo. No século XVIII, Réaumur estudou a regeneração das patas no caranguejo, Spallanzani mostrou que o caracol regenera mesmo sua cabeça, Trembley descobriu que os pólipos de água doce podem ser enxertados como as plantas (um pedaço de pólipo restitui um pólipo inteiro) ${ }^{9}$. No século XIX, Claude Bernard e depois Paul Bert anteciparam a possibilidade de colocar tecidos em cultura, o que será realizado em 1910. Desde o início do século XX sabe-se que existem, nos tecidos dos organismos adultos, "células-tronco" que são as precursoras das células diferenciadas: desta forma, o sangue regenera-se continuamente pela diferenciação das células-tronco hematopoiéticas contidas na medula óssea. A particularidade das células-tronco é que elas podem, ao mesmo tempo, multiplicar-se de forma idêntica, para restituir células-tronco, e diferenciar-se para engendrar células especializadas. Elas podem também, ao que parece, desdiferenciarem-se para rediferenciarem-se em outra via: foi demonstrado em laboratório que células hematopoiéticas de ratos que normalmente engendram células sanguíneas, podem, sob certas condições, produzir células de fígado, de músculo ou de pulmão.

As propriedades terapêuticas das células-tronco contidas nos tecidos dos corpos adultos ${ }^{10}$ já são utilizadas há muitos anos em duas indicações: coleta (durante um período de remissão), cultura e reinfusão das próprias células-tronco hemato poiéticas em doentes de leucemia que foram colocados em aplasia celular por uma quimioterapia; e coleta, cultura e transplante das células-tronco da própria pele em grandes queimados. M ais recentemente, dois brilhantes sucessos da terapia celular tornaram-se públicos na França. E m 2000, a equipe de Alain Fisher tratou "crianças-bolhas" (atingidas por um déficit imunológico de origem genética) retirando células-tronco de sua medula óssea, cultivando-as e, após modificálas geneticamente, reinfundindo-as ${ }^{11}$. Em 2001, a equipe de Philippe M énasché coletou células-tronco de um músculo da perna (mioblastos) de uma pessoa atingida por um enfarto do miocárdio; estas células foram colocadas em cultura e em seguida reinfundidas no coração onde o enxerto foi assimilado e melhorou a performance cardíaca, as células enxertadas tendo adotado o ritmo de trabal ho das células do coração. Trata-se, nestes casos, de autotransplantes. A vantagem 
técnica dos autotransplantes é que eles não provocam rejeição imunológica. 0 princípio dos autotransplantes é, em geral, considerado como isento de problemas éticos ${ }^{12}$.

$\mathrm{N}$ ão ocorre o mesmo com os al otransplantes (ou transplantes alogênicos, ou transplantes de um elemento de um ser vivo para um outro ser vivo da mesma espécie). Os alotransplantes são tecnicamente mais aleatórios do que os autotransplantes. A rejeição imunológica que eles provocam exige tomar precauções: antes do transplante, seleção dos perfis imunológicos do receptor e do doador, a fim de obter um pareamento aproximado; após o transplante, necessidade para o receptor de receber durante toda vida um tratamento imunossupressor para combater o risco de rejeição (salvo em casos onde o transplante é apenas um auxílio temporário, como no caso da transfusão de sangue). A própria depressão das defesas imunológicas comporta riscos: susceptibilidade aumentada para certas infecções e cânceres. Finalmente, apesar da presença de dispositivos de vigilância, a probabilidade residual de que o transplante transmita ao receptor um agente infeccioso (vírus, prion) presente e não detectado no doador nunca é nula. Do lado ético, o princípio dos alotransplantes é recusado por algumas comunidades (como as Testemunhas de J eová) por motivos culturais e religiosos. Sem recusar o alotransplante por princípio, foram levantadas objeções contra certos tipos de intervenção, como o transplante intracerebral de células nervosas retiradas de fetos abortados. A coleta de células vivas de um feto morto é legal na França, como toda coleta de um corpo morto. M as a maneira de proceder foi objeto de negociações delicadas referentes: às condições da coleta dos tecidos fetais, à informação da mulher sobre a utilização do produto da interrupção voluntária da gravidez (IVG) para fins de pesquisa ou terapêuticos, seu consentimento para esta utilização e à informação do receptor do transplante sobre o caráter experimental do procedimento ${ }^{13}$. Reservas morais foram também expressas em relação ao recurso a uma "criança-medicamento". A pequena M olly N ash sofria de uma anemia de Fanconi (congênita). Seus pais decidiram recorrer a uma fertilização assistida para beneficiá-la, no momento do nascimento do bebê, de um transplante de sangue do cordão umbilical (rico em células-tronco fetais). U m diagnóstico genético pré-implante foi efetuado sobre os embriões obtidos deles in vitro: 0 embrião a ser reimplantado foi selecionado de modo a ser um irmãozinho(a) para M olly, ao mesmo tempo histocompatível e isento da doença ${ }^{14}$. 0 fato de selecionar um nascituro segundo critérios de utilidade para uma outra pessoa foi julgado passível de crítica, ainda que apenas o cordão (e não o bebê) seja objeto da coleta. Finalmente, alguns testemunhos sugerem que pode haver uma dificuldade psicológica em sobreviver com o órgão de um outro. 0 filósofo J ean-L uc N ancy chama de "intruso" o coração que Ihe foi transplantado:

$N$ ão é que me abriram, fendido, para trocar de coração. É que esta fenda não pode ser fechada... Estou aberto fechado. Há uma abertura por onde passa um fluxo incessante de estranheza: os medicamentos imunodepressores, os 
outros medicamentos encarregados de combater certos efeitos ditos secundários, os efeitos que não se sabe combater (como a degradação dos rins), os controles renovados, toda a existência... varrida de ponta a ponta. A vida escaneada e relatada em múltiplos registros que, cada um, inscreve outras possibilidades de morte. Sou eu mesmo portanto, que me torno assim meu intruso... ${ }^{15}$

O s al otransplantes po deriam beneficiar-se dos desenvolvimentos contemporâneos da pesquisa sobre as células-tronco. U m centro de pesquisas na Índia acaba de anunciar a abertura de uma clínica onde as cegueiras provocadas pela deterioração dos tecidos externos do olho serão reparadas por transplantes de células-tronco adultas colocadas em cultura: um procedimento muito superior ao transplante de córnea, segundo os promotores desta técnica, porque ele permite reparar de uma vez todos os tecidos oculares externos, e não somente a córnea ${ }^{16}$. U ma vantagem adicional desta técnica é que a multiplicação das células em cultura fornece um recurso virtualmente inesgotável. Foi dito mais acima: peças para transplante (como as córneas) são um recurso escasso. Fazer transplantes para pessoas com diabetes insulino-dependente ou com a doença de Parkinson, além do mais, necessita de uma logística pesada, pois é preciso coletas oriundas de vários doadores para tratar um só receptor, que as coletas dependam das eventualidades dos óbitos ou das IVG, e que uma cadeia contínua de competências funcione para encaminhar e preparar o transplante em um prazo compatível com o seu sucesso. I magina-se que logo mais venha-se a dispor de "bancos" (ou "bibliotecas") de células beta pancreáticas secretoras de insulina, de células nervosas produtoras de dopamina, de células de sangue de cordão, colocando a disposição dos doentes e dos médicos uma fonte abundante de peças para transplante, liberada da sujeição às eventualidades da coleta. U ma das grandes esperanças da "medicina regeneradora" reside na possibilidade de tais coleções. H á uma década uma reflexão ética aprofundada tem acontecido em vários países sobre a aceitabilidade de produzir linhagens celulares a partir de células-tronco humanas, adultas ou embrionárias, e sobre as condições nas quais estas linhagens poderiam servir ao uso terapêutico ${ }^{17}$. As células-tronco dos tecidos adultos são raras e às vezes difíceis de identificar.

O s conhecimentos que permitem pensar que as células embrionárias seriam um bom recurso são relativamente recentes. Sabe-se há apenas mais de um século que um organismo vivo pluricelular como o nosso provém de uma única célula, que resulta da fusão de um ovócito e de um espermatozóide. D urante o desenvolvimento embrionário, esta célula inicial divide-se em duas, quatro, oito etc., até formar uma pequena bola de células das quais cada uma, separada das outras, pode restituir um embrião inteiro: estas primeiras células embrionárias são ditas totipotentes. Em seguida, há separação entre aquilo que irá formar 0 embrião propriamente dito e o que irá formar os anexos (como a placenta). As células do embrião no estádio blastocisto (entre o quinto e o sétimo dia após a 
fecundação, logo antes da nidação, no ser humano) não têm mais o potencial de restituir um embrião completo, mas cada uma delas tem o potencial de formar todos tipos de célula do organismo (mais de duzentos tipos celulares): elas são ditas plu ri potentese chamadas de "células-tronco embrionárias". D esde o fim do século XX, os biólogos aprenderam a cultivar linhagens destas células, primeiro no rato (1982), depois no homem (1998), e a controlar sua diferenciação em diferentes tipos celulares. Sabe-se, atualmente, produzir, desta maneira, vários tipos celulares... inclusive ovócitos e espermatozóides ${ }^{18}$.

A conscientização sobre a "plasticidade" das células-tronco embrionárias gerou grandes esperanças terapêuticas. A demanda é forte, particularmente de associações de pacientes ou de parentes de pessoas com doenças degenerativas: no fórum europeu de 2001, uma pessoa com esclerose em placa testemunhava calorosamente a favor dos experimentos de transplante de células-tronco feitos na E spanha há al guns anos com esta indicação ${ }^{19}$. 0 recurso existe e não é raro: os embriões no estádio blastocisto abandonados nos congeladores da fertilização assistida, na condição de que seus genitores não tenham mais projeto algum para eles e que aceitem destiná-los à pesquisa em vez de destruí-los, podem fornecer as células-tronco necessárias. N esta medida, será prática corrente no futuro buscar nas bibliotecas de células-tronco humanas material para reparar lesões dos ossos, das cartilagens articulares, da medula espinhal, por exemplo, das vítimas de acidentes do trânsito ou do esporte? Podemos ambicionar reconstruir desta maneira o tecido cardíaco lesado por um enfarto, o tecido hepático lesado por uma cirrose, o tecido renal? 0 transplante de células beta pancreáticas irá tornarse, por esta via, o tratamento padrão do diabético insulino-dependente? ${ }^{20} \mathrm{~A}$ ciência ainda balbucia so bre estes pontos. Para que as esperanças terapêuticas se concretizem, é preciso que se aprenda a garantir a segurança do processo de diferenciação e de multiplicação celular. U ma célula susceptível de se multiplicar e de se desdiferenciar é também uma célula susceptível de se tornar cancerosa. U ma pesquisa atenta parece indispensável, antes que nos precipitemos em direção das aplicações. Para que esta pesquisa se desenvolva, é preciso também que ela seja autorizada ${ }^{21}$. A objeção principal à sua autorização diz respeito à instrumentalização do embrião humano. M as, tratando-se de embriões destinados a serem destruídos, tende-se a argumentar da mesma forma que no caso da coleta de órgãos de corpos mortos: é difícil afirmar que a destruição seja melhor que a doação. O Grupo europeu de ética das ciências e das novas tecnologias junto à Comissão européia, mesmo afirmando que o respeito ao pluralismo está no fundamento da U nião européia, e que opções legislativas diferentes entre os países da U nião são perfeitamente aceitáveis, formulou a o pinião que "a pesquisa sobre as células-tronco visa a aliviar o sofrimento humano", e que "dificilmente podese encontrar um argumento a invocar para proibir uma ampliação do campo destas pesquisas visando a desenvolver novos tratamentos contra doenças ou lesões graves" 22 . 0 barômetro europeu das biotecnologias ${ }^{23}$ mostra que a o pinião 
dos cidadãos europeus é, em todos países da U nião, majoritariamente favorável ao desenvolvimento das biotecnologias aptas a tratar doenças humanas, e isto inclui o recurso às células-tronco embrionárias. 0 verdadeiro problema é médico. O s transplantes celulares que tornarão viáveis nossas bibliotecas de células são alotransplantes. Eles não dispensarão os médicos de controlar a compatibilidade imunológica do material e do hóspede (tipagem H LA), nem os pacientes de receber um tratamento imunossupressor a fim de combater o risco de rejeição. Este problema médico é complicado por um problema legal, recentemente destacado em um relatório americano ${ }^{24}$, porque nos Estados U nidos o número de linhagens de células embrionárias humanas sobre as quais os pesquisadores podem trabal har no setor público, foi severamente limitado. Estas linhagens foram derivadas de células embrionárias originadas essencialmente da população branca. A variabilidade dos grupos H LA de uma população para outra faz com que um paciente americano branco tenha muito mais chances que um não branco de encontrar neste acervo material celular comparável ao seu. O s autores do relatório pedem que os bancos de células-tronco embrionárias possam adotar uma estratégia de "representação étnica", a qual assegure a todas as comunidades chances iguais de acesso ao transplante celular. De qualquer modo, eles calculam que o número de linhagens cuja cultura foi autorizada é muito fraco para representar de modo razoável o polimorfismo genético da população americana: seria preciso que as bibliotecas celulares tivessem uma oferta mais rica. Sem dúvi$\mathrm{da}$, existem estratégias alternativas, como aquela que consiste em neutralizar com mais eficácia as defesas imunológicas do receptor, mas esperando que elas dêem provas de serem viáveis, o problema da rejeição imunológica continua sendo 0 maior no caso dos alotransplantes. O ra, parece que pela técnica da clonagem é possível contornar este problema, garantindo ao receptor uma espécie de autotransplante.

A técnica da clonagem consiste em substituir o núcleo de um ovócito (núcleo com $n$ cromossomos de uma célula germinativa fêmea) pelo de uma célula somática (núcleo com $2 \mathrm{n}$ cromossomos de uma banal célula do corpo). Constata-se que o núcleo assim transferido é "reprogramado" : ele recupera suas potencialidades embrionárias. A célula que resulta da transferência de núcleo é, portanto, como uma primeira célula embrionária. Esta técnica é, em si, moralmente neutra. Tudo depende do que é feito dela. A clonagem de caráter reprodutivo tem como objetivo engendrar, através desta técnica, uma criança cujo genoma seja idêntico ao do doador do núcleo transferido: um clone de seu "pai" (se imaginarmos um homem que deseje um filho idêntico a si próprio). A clonagem de caráter terapêutico busca obter através desta técnica uma linhagem celular que possa fornecer material para tratar o doador do núcleo (por exemplo, células neurais para tratar um doador que sofra do mal de Parkinson). Ruwen 0 gien, em um número anterior de $R$ aison publique, argumentou que "a clonagem não éum problema moral" 25 . Ele pensava somente na clonagem de caráter reprodutivo. Ele queria dizer que não há nenhuma boa razão de pensar que nossa espécie 
deva excluir por princí pi o este modo de reprodução. Estou de acordo com O gien neste ponto. M as há várias boas razões, inclusive morais, para pensar que nossa espécie deva se abster de reproduzir-se desta maneira. Algumas destas razões foram expostas por J aenisch e Wilmut ${ }^{26}$ em um artigo lapidar da revista Science: os experimentos de clonagem reprodutiva realizados com outros mamíferos (oveIha, rato, vaca, cabra, porca) mostram que o procedimento, além de ter um rendimento muito ruim, acarretam também um "defeito" importante nos bebês ( problemas de desenvolvimento, alta mortalidade gestacional e neonatal, diversas malformações nos sobreviventes), provavelmente ligado a uma reprogramação imperfeita do núcleo. O s autores concluem que seria "irresponsável" querer engendrar crianças nestas condições.

Trata-se claramente de um juízo moral. Sem dúvida, pode-se achar ridículo que a O rganização das $\mathrm{N}$ ações U nidas discuta sobre uma proibição mundial da clonagem reprodutiva que ela não tem como fazer respeitar. $M$ as, independentemente de qualquer especulação moralizante sobre os motivos narcísicos de quem desejaria mirar-se em seu clone, e sem mesmo evocar a dificuldade prática ( se o doador do núcleo for um homem) de que ele encontre um ovócito e, em seguida, uma barriga, acolhedores para seu núcleo, existe - fundada no risco a que estariam sujeitos os nascituros - uma argumentação moral possível contra eventuais experimentos de clonagem reprodutiva no homem, no estado atual de nossos conhecimentos e de nossa habilidade.

A clonagem terapêutica visa ao desenvolvimento, não de um indivíduo humano, mas de uma linhagem celular humana. U ma equipe sul-coreana ${ }^{27}$ recentemente provou que é possível derivar uma linhagem de células-tronco embrionárias (pluripotentes) de uma célula resultante da transferência para um ovócito humano enucleado do núcleo de uma célula somática ( no exemplo citado, uma célula pertencente à corona que circunda o ovócito: a doadora de núcleo é, neste caso, a mesma pessoa que doou o ovócito). Esta equipe, portanto, construiu, pela transferência de núcleo (i.e. por clonagem), uma célula embrionária e deixou esta célula multiplicar-se in vitro até o estado de blastocisto, após o que as células tronco pluripotentes do blastócito foram retiradas e reproduziram-se em várias gerações que conservaram características genéticas estáveis, idênticas àquelas da célula somática de onde o núcleo provinha. Elas também mostraram sua capacidade de engendrar células diferenciadas nas três vias correspondentes aos três folhetos embrionários (ectoderma, mesoderma, endoderma) a partir dos quais desenvolvem-se os principais tipos celulares do organismo. A clonagem humana de caráter terapêutico não é mais, portanto, um fantasma. 0 que isto significa? I maginemos uma mulher com diabetes insulino-dependente. E la consente em receber um tratamento hormonal indutor de ovulação, em ter coletado por punção os ovócitos produzidos e em transferir núcleos de células de seu próprio organismo para estes ovócitos. Suponhamos a transferência bemsucedida e, pronto, temos células embrionárias com um genoma idêntico ao 
desta mulher. Se conseguirmos direcionar e estabilizar a diferenciação de uma linhagem celular oriunda dessas células embrionárias para a via da fabricação de células beta pancreáticas produtoras de insulina, poderemos propor-Ihe um transplante imunocompatível - um autotransplante - para equilibrar seu diabetes. Em teoria esta solução é muito sedutora. Aqui não é preciso recorrer a um "banco" que forneça material para transplante mais ou menos comparável, nem que 0 paciente submeta-se a um tratamento imunossupressor, mas tem-se uma construção pontual ajustada ao perfil imunológico de um ser individual. $\mathrm{N}$ a prática, é preciso reconhecer que estamos ainda muito longe da aplicação terapêutica. 0 fraco rendimento do método é uma primeira dificuldade: a equipe coreana estimulou a ovulação em dezesseis mulheres (informadas sobre o projeto e participantes voluntárias); 242 ovócitos foram recolhidos, sobre os quais foi praticada uma transferência de núcleo; cerca de trinta embriões foram obtidos, os quais desenvolveram-se até o estado de blastocisto, e um só desses embriões produziu linhagens celulares que puderam ser cultivadas. É dificilmente concebível que tantos recursos sejam mobilizados para cada paciente à espera de um transplante, mas é praticamente certo que a técnica irá melhorar. U ma segunda dificuldade decorre de que somente as mulheres em idade de procriar fabricam ovócitos: se o diabético de quem se tratava for um homem, ele fornecerá o núcleo a ser transferido, mas precisará recorrer a uma doação de ovócito. Entre as objeções de princípio à clonagem terapêutica, o risco da exploração das mulheres doadoras foi freqüentemente citado; na realidade, especialistas de fertilização assistida respondem que a coleta de ovócitos de corpos (mortos) acidentados, ou de peças operatórias separadas do corpo, seriam suficientes para cobrir a demanda. As dificuldades técnicas não são, portanto, de modo algum insuperáveis. Permanece uma terceira dificuldade, que é ética ou cultural.

É paradoxal, à primeira vista, que a pesquisa sobre a clonagem terapêutica seja proibida em certos países (como na França e na I tália) e autorizada em outros (como nal nglaterra, na Suécia, na Coréia do Sul, em I srael) e que a "clonagem humana" (todas finalidades confundidas) tenha sido condenada com veemência por políticos (como o Presidente dos Estados U nidos) ou instituições (como o

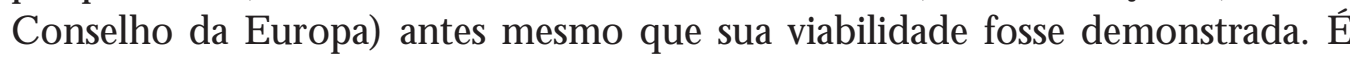
preciso que as implicações éticas e/ ou políticas sejam particularmente sensíveis para que o recente resultado coreano seja comentado timidamente por cientistas respeitáveis (como Axel Kahn e N icole L e D ouarin ${ }^{28}$ ). U ma associação internacional que milita por um "humanismo laico" nega porém que a clonagem coloque questões éticas mais graves do que outras inovações tecnológicas:

os futuros desenvolvimentos da clonagem de tecidos humanos ou mesmo de seres humanos não podem criar dificuldades de natureza moral cuja resolução iria além da capacidade da razão humana. As questões morais levantadas pela clonagem não são nem mais importantes nem mais profundas do que aquelas às quais os seres humanos já foram confrontados a respeito de tecnologias 
como a energia nuclear, as recombinações de D N A ou a cifragem dos computadores. Elas são apenas novas ${ }^{29}$.

O coração do problema é que no domínio cultural ocidental, a sacralização do ato humano procriador, ligada a uma cultura judaico-cristã (ou a seus componentes mais fundamentalistas), induziu fortes resistências à interrupção da gravidez, a todas as técnicas de fertilização assistida e à instrumentalização do embrião humano, todas elas consideradas como faltas ao respeito devido ao ser humano na medida em que sua existência responde a um projeto divino: "D esde o seio materno l ahweh me chamou, desde o ventre de minha mãe, pronunciou o meu nome", diz a Bíblia ${ }^{30}$.

N ospaíses onde a lei proíbe qualquer forma de clonagem terapêutica, os principais argumentos alegados a favor da proibição são que a célula obtida pela transferência de núcleo é um embrião potencial que, se fosse implantado em um útero, seria susceptível de desenvolver-se em um ser humano completo; e que passaremos, portanto, muito facilmente, da clonagem terapêutica para a reprodutiva. Ainda que os dois argumentos sejam próximos, eles têm uma tonalidade muito diferente. 0 segundo é do tipo "argumento da encosta escorregadia", e como todo argumento deste tipo, é fácil de refutar: nossas sociedades sempre souberam fixar os limites que não devem ser

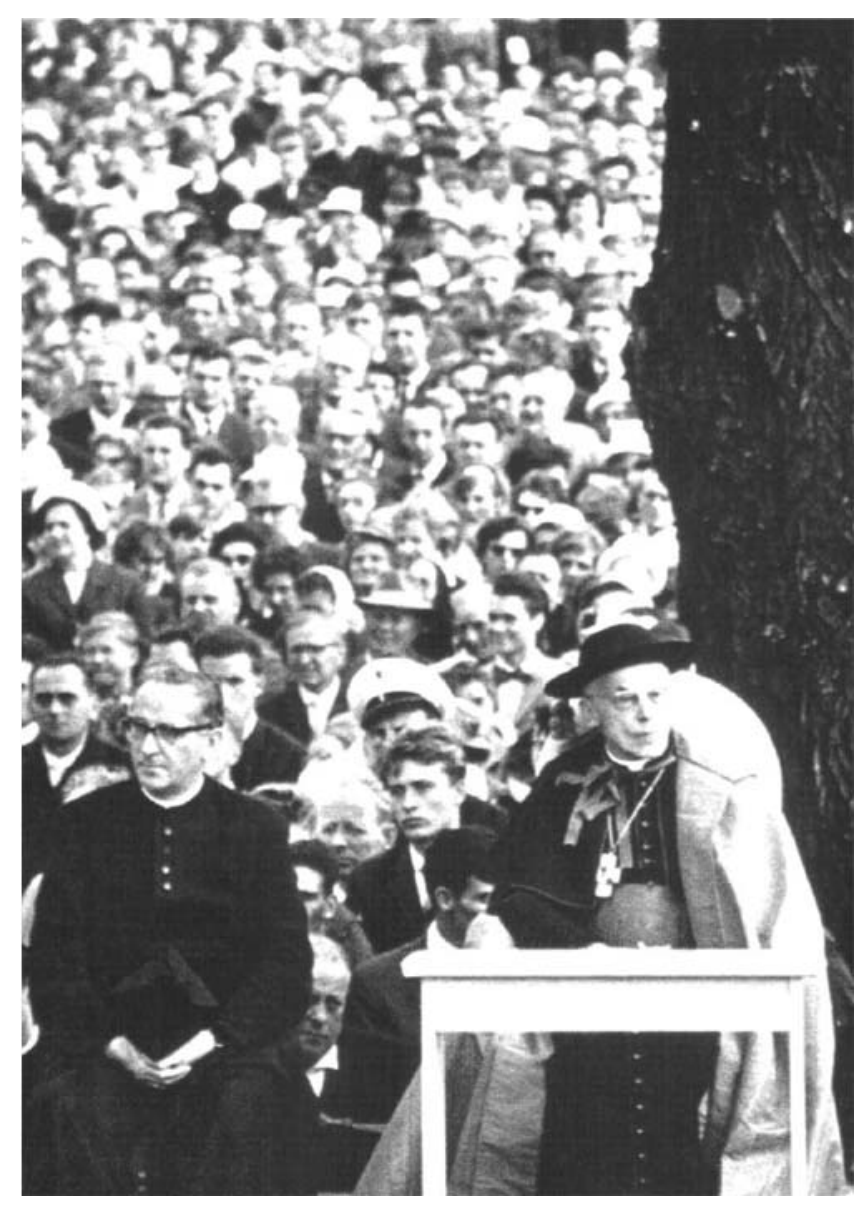

Encontro campal da I greja Católica.

transpostos, e penalizar os contra-ventores. N ão se transfere um embrião no estado de blastocisto para o útero de uma mulher por acaso ou por distração. 0 primeiro argumento repousa sobre o pressuposto de que a célula obtida pela transferência de núcleo tem a dignidade do embrião humano; e aquele que considera que um embrião humano já é uma " pessoa humana" com todos os direitos da pesso a julgará escandalosa a eventualidade de instrumental izar esta célula. 
$M$ as é filosoficamente muito questionável confundir uma "célula humana" com uma "pessoa humana” . A própria I greja católica durante muito tempo defendeu a doutrina da "animação mediata", que dizia que D eus infunde a alma no ser humano em gestação após ele ter atingido um estágio suficiente de desenvolvimento (por volta de três meses), e Tomás de Aquino admitia que antes desta "animação" o aborto não é um homicídio31. A "personalização" do embrião humano desde o ato fecundador que produz a primeira célula embrionária pode, a rigor, ter sentido através do projeto parental de levar este ser à personalidade, mas não tem sentido ao se tratar de um embrião não acolhido por ventre mater-

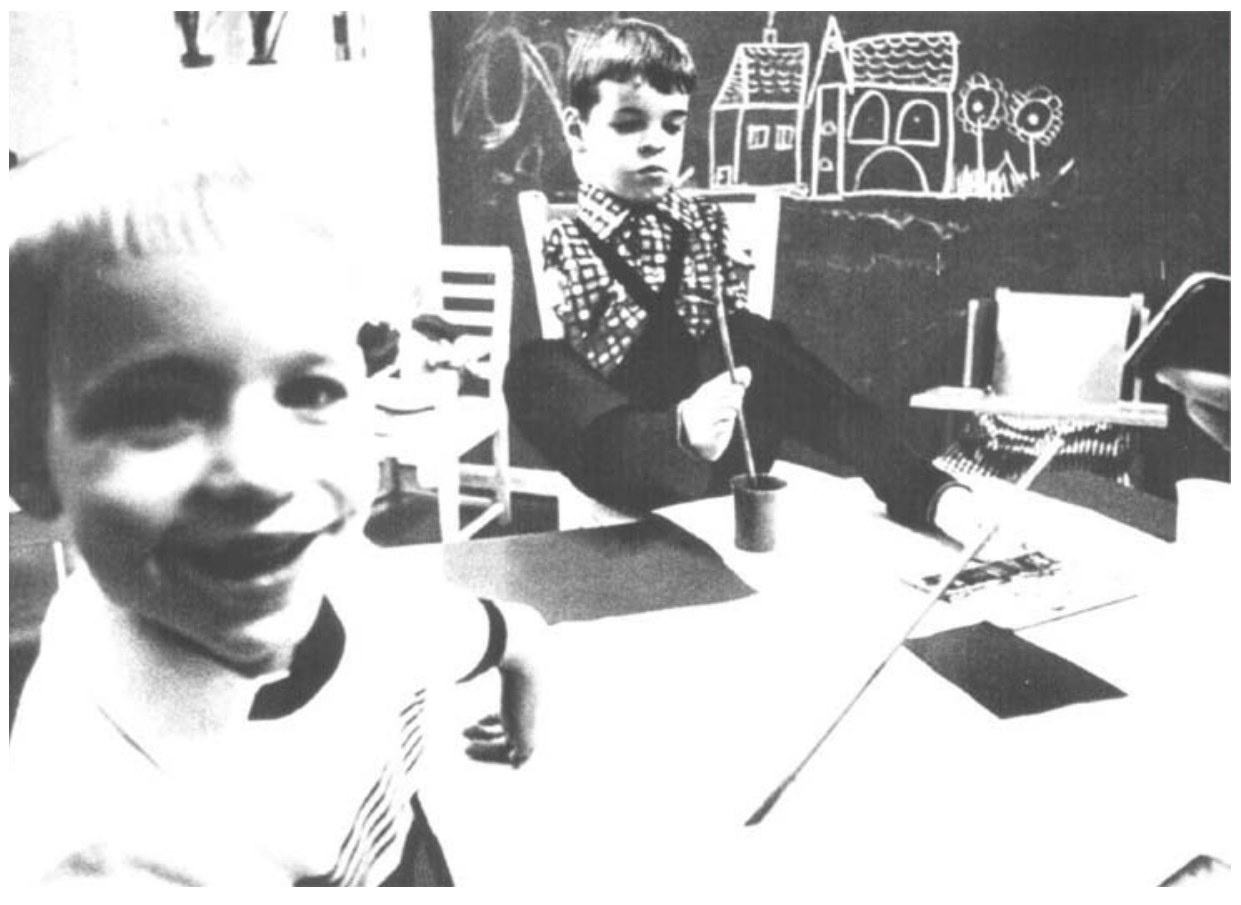

Criançasdeficientesfísicas em atelier de pintura. no algum, eque não tem por si próprio capacidade alguma de afirmar-se como sujeito moral. A noção de "pessoa humana potencial" tinha sido conservada pela Comissão consultiva nacional de ética francesa, para significar que 0 embrião humano éprecioso em razão da capacidade que ele tem de tornar-se um ser pessoal, na hipótese de que encontre um útero para sua nidação, e uma sociedade para sua educação. M as nenhuma moral diz que todo ser potencial deve ser atualizado. E seria tanto mais absurdo dizê-lo no momento em que a biologia nos ensina que to das as células de nosso corpo, em to do caso todas suas célulastronco, têm um potencial embrionário.

N os países onde a lei autoriza a clonagem terapêutica, proibindo ao mesmo tempo a clonagem reprodutiva, as dificuldades morais previsíveis provavelmente não surgirão de tentações que os pesquisadores teriam de passar para a clonagem reprodutiva. Elas surgirão de eventuais divergências de visão sobre a melhor forma de obter e de estabilizar linhagens de células preparadas em vista de transplantes. $\mathrm{O} u$ bem as linhagens celulares são cultivadas e estabilizadas in vitro, ou bem pode-se ficar tentado a implantar em um útero humano a célula obtida pela transferência de núcleo, e deixá-la desenvolver-se até o estágio em que os tecidos que se deseja utilizar para o transplante tenham começado a dife- 
renciar-se. Se o beneficiário potencial do transplante for do sexo masculino, esta estratégia implica que ele instrumentalize uma mulher (eventualmente sua muIher) para este início de uma gravidez destinada a ser abortada, e está claro que há um ponto problemático nesta hipótese. Se o beneficiário do transplante for do sexo feminino, salvo se for argumentado que uma mulher não é livre para dispor do seu corpo, pode-se excluir a hipótese de que ela utilize seus próprios recursos fisiológicos para proporcionar-se os meios de uma terapia reparadora? U ma mulher diabética poderia hospedar no seu corpo um embrião cujo núcleo proviria de uma de suas próprias células somáticas, e que seria destinado, ao final de algumas semanas, a fornecer-Ihe as ilhotas de L angerhans (células beta pancreáticas) de que ela necessita? Pode-se fazer isto e respeitar a si próprio? N este limite a reflexão moral vacila. O s problemas colocavam-se até aqui bastante naturalmente nos termos de uma moral do bem e/ ou da eqüidade, eis que oscilamos em direção a uma moral do dever. $\mathrm{N}$ ão se trata de argumentar que o embrião humano, desde seus primeiros estágios de desenvolvimento, é objeto de respeito, portanto intocável. 0 respeito, no sentido kantiano, destina-se ao agente moral, isto é, a um ser capaz de se autodeterminar, de se comportar segundo a representação que ele tem do imperativo moral. U m embrião no estado de blastocisto não tem autonomia moral. Aqueles que têm sua autonomia moral são os adultos beneficiários dos transplantes, os pesquisadores e os assistentes que desenvolvem as técnicas, os representantes do povo que fazem as leis, todos nós representados por eles e que nos perguntamos se, neste universo que se pretende solidário ao ponto de trocar elementos do corpo para tratar aqueles que estão doentes, existem limites que não devem ser transpostos ao preço de atentar contra a dignidade humana. $\mathrm{N}$ ossa dignidade exprime-se na recusa seletiva de certas técnicas reparadoras ou, ao contrário, na doação, talvez na engenharia, de tecidos reparadores? H á um risco moral em "recortar" células humanas, além do risco biológico bem real decorrente de eventuais inabilidades nas manipulações?

U m país que encoraja o desenvolvimento das biotecnologias, e particularmente a pesquisa sobre a clonagem terapêutica, como a Coréia do Sul, corre o perigo de perverter-se, e de que perversão se trata, da qual um país como o nosso proteger-se-ia proibindo este tipo de pesquisa? Existem domínios de pesquisa que uma espécie humana que se respeita deve evitar de explorar? É preciso apenas assinalar (retornando sensatamente a uma moral do bem) que no contexto de um sistema de saúde com recursos necessariamente limitados, investir muito dinheiro e energia no transplante e na clonagem terapêutica é uma opção, e que existem outras alternativas possíveis em termos de alocação de recursos... Aos especialistas de filosofia moral e política cabe propor balizas que possam guiar nossos juízos sobre estes assuntos delicados. U ma coisa parece clara: a questão daquilo que o ser humano pode autorizar-se a fazer sem perder o respeito por si próprio não é uma questão de ontologia biológica. 


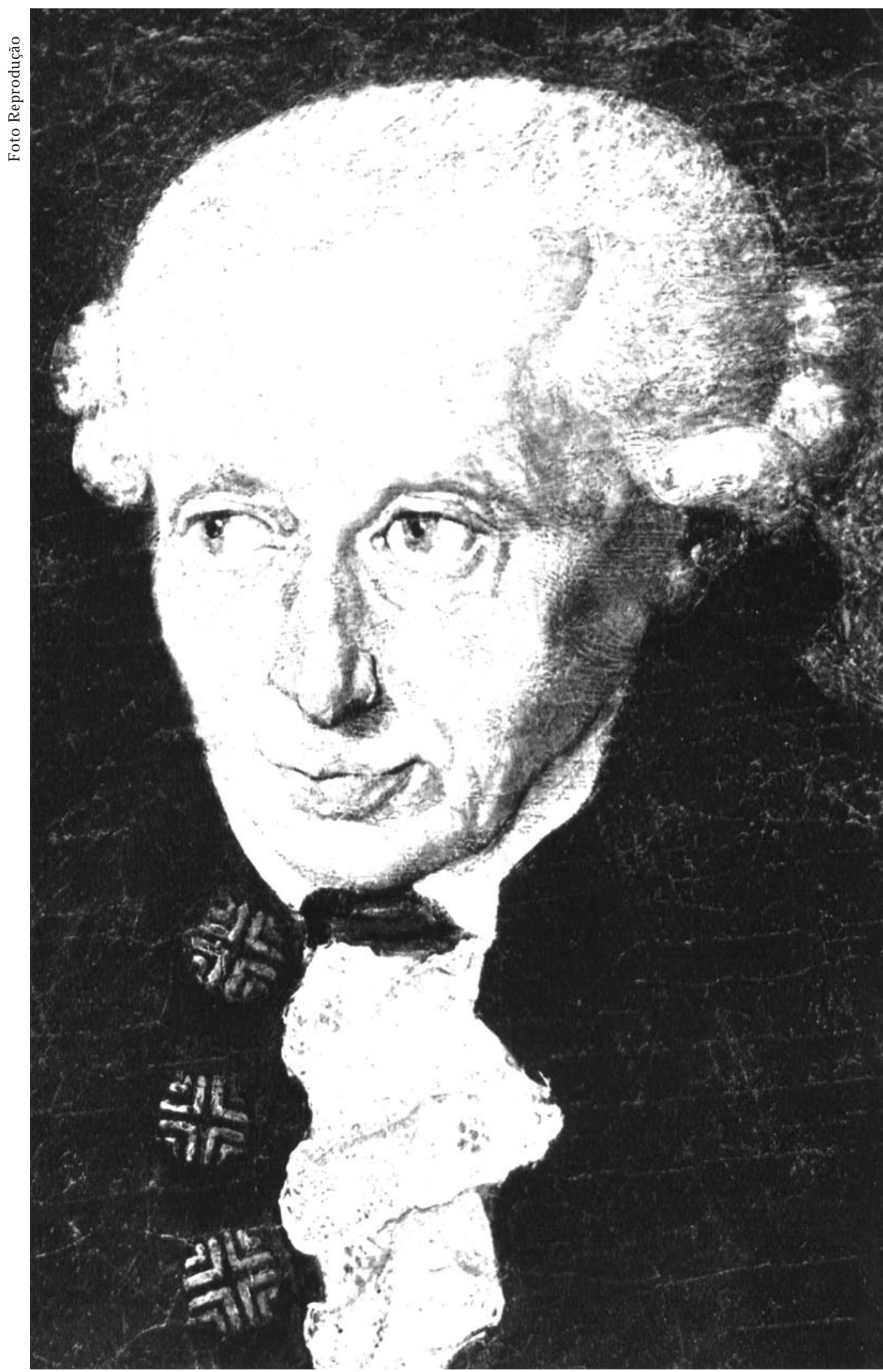

O filsósofo alemão Emmanuel K ant (1724-1804), autor de A crítica da razão pura (1781). 


\section{N otas}

1 Sobre a organização das coletas, ver: K. Bensalah; M. Bitke e B. Barrou, "Aspects organisationnels des prélèvements multiorgane em France" , J ournal de chirurgie, 2004, 141 (1): 5-10. U ma perspectiva antropológica: Claire Boileau, D ansle dédale du don d'organes, Paris, Editions des Archives Contemporaines, 2002.

20 s problemas da reconstrução da face pelo alotransplante foram recentemente examinados pela Comissão consultiva nacional de ética: "L'allotransplantation de tissu composite (ATC) au niveau de la face (greffe totale ou partielle d'un visage)", noㅡ 82, 6 fev. 2004, www.ccne-ethique.fr.

3 Amitai Etzioni, "O rgan D onation: A Communitarian Approach", 1-18; Robert M. Veatch, "Why L iberals Should Accept Financial I ncentives for O rgan Procurement", 19-36; Clifford Earle Bartz, "O peration Blue, U Itra: DIO N - The D onation Inmate O rgan N etwork", 37-44; J effrey P. Kahn, "T hree Views of O rgan Procurement Policy: M oving Ahead or Giving U p?", 45-50; Alexander S. Curtis, "Congress Considers Incentives for Providing O rgans", 53-64; K ennedy I nstitute of Ethics) ournal, The Johns H opkins U niversity Press, 2003, 13 (1).

4 Robert Titmuss, The Gift R elationship, N ew York, Pantheon Books, 1971.

5 Lei no 94-653 de 29/ 7/ 1994 relativa ao respeito pelo corpo humano, J0, 30 jul. 1994, 11056-59.

Lei no 94-654 de 29/ 7/ 1994 relativa à doação e à utilização de elementos e produtos do corpo humano, à assistência médica à fertilização e ao diagnóstico pré-natal, J 0 , 30 jul. 1994, 11060-68.

Lei no 94-548 de 1ㅇ 7/ 1994 relativa ao tratamento de doações nominativas tendo por fim a pesquisa no domínio da saœde e modificando a lei no 78-17 de 6 jan. 1978 relativa à informática, aos fichários e às liberdades, J 0 , 2 jul. 1994, 9559-60.

6 Projeto de lei relativo à bioética, Bulletin spécial, D ictionnairePermanent Bi oéthi que et Biotechnologies, 10 (5): no 124, 10 mar. 2003; ou <www.sante.gouv.fr/ htm/ actu/ bioethiq/ 34_010620>.

7 U m porco "humanizado" é aquele para o qual são transferidos genes humanos com a finalidade de atenuar a dupla reação imunológica do material transplantado contra o hospedeiro do transplante, e do hospedeiro contra o material; esta reação é mais forte entre espécies diferentes do que no interior da mesma espécie.

$8 \mathrm{H}$ astings $\mathrm{C}$ enter $\mathrm{R}$ eport, 1978, 8 (5): 5-6.

9 J ean Rostand, A ux sources de la biologie, Paris, Gallimard, 1958.

10 A cadémie des sciences, D ela transgen èse ani maleà la bi othér api e chez l'homme, sob a direção de M oshe Yaniv, RST no 14, Paris, Lavoisier (Tec \& D oc), 2002.

11 Este experimento foi saudado como um sucesso exemplar da terapia gênica. Ele foi interrompido, assim como outros experimentos similares, na G rã-B retanha e nos Estados U nidos, após a ocorrência de complicações em algumas das crianças tratadas pela equipe do hospital N ecker. A elucidação do mecanismo das complicações possibilitou a retomada dos experimentos.

12 A autotransfusão foi algumas vezes estigmatizada na França, como indicadora de uma 
vontade egoísta de subtrair-se à regra da solidariedade. D esde a revelação da contaminação pelos vírus da Aids e da hepatite $C$ de inœmeras pessoas que receberam transfusões de sangue (1993), a autotranffusão é encorajada por razões de segurança.

13 Comité Consultatif $\mathrm{N}$ ational d'Éthique français pour les sciences de la vie et de la santé. A vis sur les greffes de cellules nerveuses dans le traitement de la maladie de Parkinson, 1989, № 016. Avis concernant des greffes intracerebrales de tissus mésencéphaliques d'embryons humains chez cinq malades parkinsoniens dans un but d'expérimentation thérapeutique, 1990, no 023; http:/ / www.ccne-ethique.org.

14 Y. Verlinsky et al., "Preimplantation D iagnosis for Franconi Anemia Combined with H LC M atching", JAM A, 2001, 285: 3130-3133.

15 J ean-Luc N ancy, L'I ntrus, Paris, Galilée, 2000, p. 36.

16 N ature, 5 fev. 2004, 427:478.

17 Ver por exemplo: Comité $C$ onsultatif $\mathrm{N}$ ational d'E thique français pour les sciences de la vie et de la santé, no 052: A vis sur la constitution de collections de tissus et organes embryonnaires humaines et leur utilisation à des fins scientifiques, 1997; no 053: Avis sur la constitution de collections de cellules embryonnaires humaines et leur utilisation à des fins thérapeutiques ou scientifiques, 1997; no 054: Réponse au Président de la Republique au sujet du clonage reprodutif, 1997; http:/ / www.ccneethique.org. U S N ational Bioethics Advisory Comission (N BAC), Ethical I ssuesin H uman Stem C ell R esearch (3 vols.), R ockville, M aryland, N BAC, set. 1999, http:/ / www.bioethics.gov. Stem Cell R esearch and R egulations under the H uman Fertilisation and Embriology A ct 1990, UK, H ouse of Commons Library, revised edition, 2000. U S D epartment of H ealth, Stem C ell R esearch: M edical Progresswith R esponsibility, A Report from the Chief M edical O fficer's expert group reviewing the potential of developments in stem cell research and cell nuclear replacement to benefit human health. Washington DC, jun. 2000. Canadian Institutes of $\mathrm{H}$ ealth Research / I nstituts de recherché en santé du Canada ( CI H R/ IRSC), R echerchesur les cellu les souches humaines. La santé dans un cadre éthique, O ttawa, 2001. D anish Council of Ethics. Cloning. Copenhagen, 2001.

18 N ature, 8 jan. 2004, 427: 106-107.

19 European Comission, Research D.G. / Life Sciences Directorates, Stem Cells. Therapies for the Future?, L uxembourg L-2985: O ffice for O fficial Publications of the European Communities, 2002, http:/ / www.europ.eu.int/ comm/ public opinion/ archives/ . Ver também: R ecommandation du panel de citoyens malades ou parents de malades en matière de recherche sur les cellules souches et le clonage thérapeutique, Paris, Association Française de lutte contre les M yopathies (AFM), 2003, http:/ / debat-cellulessouches.ifrance.com.

20 Conseguir a transformação de células-tronco embrionárias em células beta pancreáticas produtoras de insulina é um programa que motiva fortemente os pesquisadores; inúmeros experimentos nesta direção foram realizados nestes últimos anos, com resultados distintos; as dificuldades parecem maiores do que foi previsto; ver: Science, 17 jan. 2003, 299: 324, 363.

21 Para um sobrevôo das posições na E uropa, ver: European Commission / Research D irectorate General, Survey on opini onsfrom $\mathrm{N}$ ational Ethics Committees or s milar 
bodies, public debateand national legi sation in relation to human embryonic stem cell research and use, edited by $L$ ine $M$ atthiessen, Bruxelles: EC D irectorate E, Biology, Agriculture and Food, 2003.

22 The European Group on ethics in science and new technologies to the European Commission / LeGroupe européen d'éthique des sciences et des nouvellestechnologies auprès de la Commission européenne, A doption of an Opinion on Ethical A spects of H uman Stem Cell R esearch and U se/ A doption d'un A vis sur les aspects éthi ques de la recherche sur lescellules souches humaines et leur utilisation, Paris: 2000, révisé 2001.

23 G eorge Gaskell; N ick Allum e Sally Stares (M ethodology I nstitute, L ondon School of Economics), Europeans and Biotechnology in 2002. Eurobarometer 58.0 (2nd Edition: March 21, 2003), A Report to the EC Directorate General for Research from the project "L ife Sciences in European Society" Q L G 7-CT-1999-00286.

24 Ruth R. Faden et al., "Public Stem Cell Banks: Considerations of J ustice in Stem Cell Research and Therapy", H astings Center R eport, dez. 2003, 33 (6): 13-27.

25 Ruwen $\mathrm{O}$ gien, “Le clonage n'est pas un problème moral”, R aison publique, 2003, 1: 83-103.

26 Rudolf Jaenisch e Ian Wilmut, "D on't Clone H umans!”, Science, 30 mar. 2001, 291 (5513).

27 W. S. H wang et al., "Evidence of a Pluripotent H uman Embryonic Stem Cell Line Derived from a Cloned Blastocyst", Science, 12 fev. 2004, online.

28 Le M onde, 13 fev. 2004; Libération, 13 fev. 2004.

29 C ouncil for secular humanism, "D eclaration in D efense of Cloning and the Integrity of Scientific Research", Frœl nquiry M agazine, 1997, 17 (3), www.secularhumanism.org.

30 I saías, 49, 1.

31 Thomas d'A quin, Somme théol ogique, II , 2, Q uestion 64, Art. 8. Para um comentário ver: A. Fagot- L argeault e G. D elaisi de Parseval, "L es droits de l'embryon humain et la notion de personne humaine potentielle", R evue de métaphysi que et de morale, 1987, 3: 361-385.

A BSTRACT - AS THE possibility of therapeutic cloning in humans has just been demonstrated by a Corean group of researchers, the paper argues that biotechnologies of that kind may contribute to alleviate the chronic shortage of organs and tissues for transplantation. Ever since immunosuppressant drugs have become available, transplantation surgery has made considerable progress, and the procurement of transplants, especially from living donors, has been problematic. The investigation of the properties of (adult or embryonic) stem cells opened great hopes. Conditions such as diabetes, multiple sclerosis, myocardial infarct, or neurodegenerative diseases (Parkinson's, Alzheimer's, $\mathrm{H}$ untington's diseases), could be treated by cellular therapy, namely, transplantation of human cells issued from cell lines derived from human stem cells possibly stored in cell banks. Adult stem cells, however, are rare and difficult to identify (apart from bone marrow, which contains the precursors of blood cells, a resource already widely used). There exists a large supply of human embryonic stem cells in countries where the freezing 
of embryos for the purposes of medically assisted procreation leaves 'spare' or 'surplus' embryos which may be either destroyed or donated for research after couples have fulfilled their procreative aim. It is often considered that harvesting stem cells from those embryos, for use in research or therapeutics, is morally more acceptable than destroying them. But the constitution of stem cell banks is open to two objections. First, in order to offer H LA compatible grafts to a large population, the bank should offer a selection of cell supplies representative of all HLA types in the population, a virtually impossible task. Second, with H LA compatible grafts there remains a risk of immunorejection, and a necessity for the patients treated to take immunosuppressant drugs for the rest of their lives. Should biological research establish their feasibility and safety, cloning techniques might then appear to be the best choice. Treating (for example) diabetic patients with cells constructed by transferring the nucleus of a somatic cell of the patient into an enucleated oocyte would have the double advantage that the graft would be immunocompatible with the receiver, and that cell banks would not be required; instrumentalizing women for the collection of oocytes has been found objectionable, but a $\mathrm{C}$ hinese group of researchers suggested the possibility of using animal oocytes. It remains that such practices have raised lots of ethical controversies. It is at this moment difficult to assess their impact on our vision of 'humanity'.

A nne Fagot-Largeault é membro da Academia de Ciências da França e professora do Collège de France, onde ocupa a $\mathrm{C}$ átedra de Filosofia das $\mathrm{C}$ iências Biológicas e $\mathrm{M}$ édicas. É psiquiatra junto à Assistência Pública de Paris. Autora, entre outras obras, de: Causual vs. Teleological Explanation of Bahavior. Stanford U niversity Press, 1971; M édecineet probabilités Paris, D idier, 1982; L'hommebio-éthique. Paris, M aloine, 1985; Lescau ses dela mort. H istoi re naturelle et facteursderisque. Paris, Vrin, 1989; L'éthique envi ronnementale. Paris, Sens, 2000; Phi losophi edessci ences (com Andler e Saint-Sernin). Paris, Gallimard, 2002.

Conferência feita pela autora em 26 de abril de 2004 no I nstituto de Estudos A vançados da U SP, no âmbito da Cátedra Claude L évi-Strauss (C onvênio entre a U SP e o Collège de France).

Tradução de R ené V. L enard. $O$ original em francês- Embryons, cellulessoucheset thérapies cellulaires: questions phi losophiques et anthropol ogi ques- encontra-se à disposição do leitor no IEA-U SP para eventual consulta. 